\title{
Changing trends and perceptions of sea turtle egg consumption in Redang Island, Malaysia
}

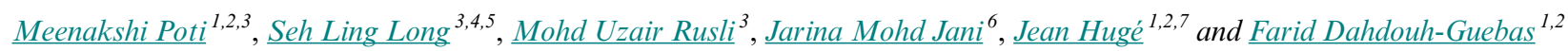

\begin{abstract}
Sea turtles have been exploited at unsustainable rates globally. In Malaysia, their populations have faced serious declines because of diverse anthropogenic stressors including turtle egg consumption. Redang Island, off the northeast coast of Peninsular Malaysia, is an important rookery for green sea turtles (Chelonia mydas) in Southeast Asia. The local community has depended on turtle eggs as a food and livelihood source for decades. Owing to the precipitous decline in sea turtles, the main nesting beaches became legally protected in 2007. Some turtle egg consumption continues despite the protection measures and long-term awareness raising. In our study, we assess the prevalence, motivations, demographic factors, and perceptions influencing turtle egg consumption and conservation. Through semi-structured interviews, we surveyed 73 respondents in Redang village. The interviews show that turtle egg consumption has decreased since the initiation of protection measures, making the eggs expensive and difficult to access. Using binary logistic regression, we found that the respondents' education level and occupation were significant predictors. Education level was negatively correlated with age. People with higher levels of education (younger people) were less likely to eat turtle eggs, possibly on account of changing cultural beliefs and taste preferences, as well as increasing awareness. Those working in the tourism industry were less likely to consume eggs. The growth in tourism has served as an alternative to livelihoods that were dependent on the consumptive use of natural resources such as fishing and turtle egg collection. Further, tourism has catalyzed a shift from consumptive to nonconsumptive uses of sea turtles. Many locals perceived the protection of beaches as important, without which they claimed that turtle populations would go extinct. This research shows that addressing sea turtle conservation requires a multi-targeted approach of regulating sea turtle egg collection, providing economic alternatives such as tourism and long-term awareness raising.
\end{abstract}

Key Words: behavior change; human-sea turtle interactions; local livelihoods; sea turtle eggs; social-ecological system; South China Sea; wildlife consumption

\section{INTRODUCTION}

Human exploitation of sea turtles has occurred at unsustainable rates (Garland and Carthy 2010), leading to significant population declines and six of the seven species "threatened with extinction" (IUCN 2020). In many parts of the world, sustained conservation efforts, fishery management, and regulatory measures have recently resulted in the gradual stabilization and increase in sea turtle subpopulations (Godley et al. 2020). However, some subpopulations show large declines (Mazaris et al. 2017). In addition to their natural vulnerability, sea turtles are impacted by diverse anthropogenic stressors, both in the ocean and on land (Frazier 2003). These stressors vary across regions, but mainly include habitat loss and degradation, climate change, fisheries bycatch, and consumptive use of turtle eggs, meat, and other parts of the animal (Nada and Casale 2011, Mazaris et al. 2017).

For millennia, sea turtles have been integral to the culture, livelihood, and economy of many communities (Campbell 2003). Their eggs are used as food, traditional medicine, and traded commodities (Delgado and Nichols 2005, Sardeshpande and MacMillan 2019). With increased demand from the wildlife trade industry, traditional harvesting of turtle eggs for subsistence has largely evolved into income-driven commercial exploitation in many parts of the world (Mancini and Koch 2009, Garland and
Carthy 2010, Mohd Jani et al. 2020). More recently, sea turtles are recognized for their non-consumptive values as flagship species for conservation and symbols for commercial purposes such as tourism (Waylen et al. 2009, Godley et al. 2020). Studies from Australia (Tisdell and Wilson 2002), Indonesia (Putra and Bailey 2007), Brazil (Pêgas 2009), Costa Rica (Campbell 2007, Mejías-Balsalobre et al. 2021), and Nicaragua (MadrigalBallestero and Jurado 2017) show that tourism as a local economic alternative has helped reduce the commercialization and consumption of turtle eggs.

Given the complexity in human-sea turtle interactions, research and engagement with the human dimensions of conservation across social, cultural, and economic contexts is critical. Cultural practices such as sea turtle egg consumption are dynamic, influenced by changing social norms and by the community's exposure and access to different knowledge types and resources (Campbell 2003). Gaining insights on the people's demographics, perceptions, and consumption patterns and the links between these aspects will help design appropriate behavior change interventions relevant to the context (Campbell 2010, MejíasBalsalobre et al. 2021). Moreover, to understand consumption behavior it is also necessary to examine how people perceive the conservation status of, threats to, and importance of sea turtles (Pêgas 2009, Senko et al. 2011).

${ }^{1}$ Université libre de Bruxelles, Faculty of Sciences, Department of Organism Biology, Systems Ecology and Resource Management Research Unit (SERM), Brussels, Belgium, ${ }^{2}$ Vrije Universiteit Brussel, Faculty of Sciences and Bioengineering Sciences, Department of Biology, Brussels, Belgium, ${ }^{3}$ Universiti Malaysia Terengganu, Institute of Oceanography and Environment, Kuala Nerus, Malaysia, ${ }^{4}$ Perhentian Turtle Project, Perhentian Islands, Malaysia, ${ }^{5}$ Lang Tengah Turtle Watch, Kuala Lumpur, Malaysia, ${ }^{6}$ Universiti Malaysia Terengganu, Faculty of Science and Marine Environment, Kuala Nerus, Malaysia, ${ }^{7}$ Open University of the Netherlands, Faculty of Science, Department of Environmental Science, Heerlen, the Netherlands 
Fig. 1. Timeline indicating the sea turtle conservation history of Redang Island. Licensed egg collection was initiated by the Terengganu State government in the 1950s. A Fisheries Prohibited Area was established in 1983. Licensed egg collection was offered to the local cooperative in 1989. Conservation efforts to incubate turtle eggs also began in the 1980s. Because of the severe decline in sea turtles in Redang, the Sea Turtle Research Unit (SEATRU) was set up in 1993. In 1994, Redang Island and the surrounding islets were gazetted as a Marine Park. In 1996, SEATRU initiated an awareness program for Redang school children that continued for 18 years. Mak Kepit beach was removed from the tender system in 1998. In 2005, the tender system was fully abolished for all beaches on Redang Island. In 2007, the five main nesting beaches in Redang Island were gazetted as sanctuaries.

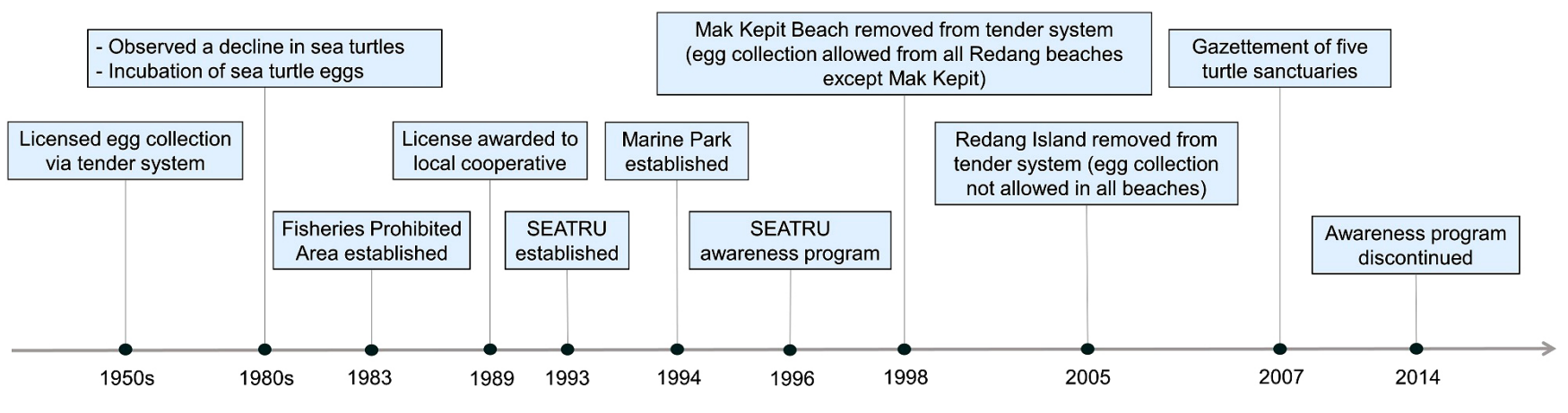

Sea turtle conservation requires diverse approaches because sea turtles are a migratory species that are influenced by jurisdictions of several states. Existing studies on the consumptive use of sea turtles predominantly focus on Latin America (Campbell 1998, Pêgas 2009, Garland and Carthy 2010, Sardeshpande and MacMillan 2019, Mejías-Balsalobre et al. 2021), with limited information on other regions including Southeast Asia.

Sea turtle egg consumption and conservation in Malaysia Malaysia holds a high number of sea turtle rookeries in Southeast Asia (Shanker and Pilcher 2003). Four sea turtle species, namely the green (Chelonia mydas), hawksbill (Eretmochelys imbricata), olive ridley (Lepidochelys olivacea), and leatherback (Dermochelys coriacea), are extant in the waters and coastal areas of the country (Chan 2006). All four species have faced serious population decline on account of various stressors, including turtle egg consumption (Shanker and Pilcher 2003). Prior to the 1980s, $90 \%$ to $100 \%$ of turtle eggs were collected for consumption in the nesting beaches of Peninsular Malaysia (Siow and Moll 1982).

Traditionally, sea turtle eggs are the only consumed part of the animal and their trade is regulated (Abd Mutalib et al. 2013). All matters relating to the conservation and monitoring of sea turtles are regulated by the state governments, the sub-national entities in the federal system of Malaysia (Zulkifli and Sankar 2011; Appendix 1). Terengganu State, with the highest sea turtle nesting density in Peninsular Malaysia, has a long history of turtle egg consumption and conservation (Siow and Moll 1982). Since the promulgation of the Terengganu Turtle Enactment of 1951, the harvest of turtle eggs is regulated such that the license to collect turtle eggs on specified nesting beaches is offered to the highest bidder via a tender system. The tender system generates revenue to the state government (Siow and Moll 1982) and resolves ownership conflicts between egg collectors (Liew 2011). Since the 1980s, high-density nesting beaches became fully protected over the years and thus no longer available for tender (Mohd Jani et al. 2020).
The sale and consumption of leatherback turtle eggs are banned in Terengganu since 1989, but the ban is not extended to the other sea turtle species. Thus, consumption continues and the sustained demand for turtle eggs in the Terengganu markets remains high (TRAFFIC Southeast Asia 2009). Visits to the main Kuala Terengganu market showed that the price of a single turtle egg ranged from 3 to 7 MYR (US\$0.69 to US\$1.62), depending on the season, source, and freshness of eggs. It is important to note that in areas where sea turtle parts have always been consumed, a total consumption ban often results in poaching (Mancini and Koch 2009, Migraine 2015).

\section{The Redang Island case study}

Redang Island in Terengganu State exemplifies the challenges and opportunities facing sea turtle conservation in many parts of the world. The island is one of the most important sea turtle rookeries and tourist destinations in Southeast Asia. Turtle eggs have played a key role as a source of food and livelihood for decades (Mohd Jani et al. 2020). There have been several conservation measures to address the overexploitation of turtle eggs in Redang Island (see Fig. 1 for a timeline of sea turtle conservation history). Licensed turtle egg collection, through the tender system, was initiated and managed in the 1950 s by the Terengganu State government. In 1989, a local cooperative known as Koperasi Setiajaya Pulau Redang (KSPR) was set up and awarded the license to collect turtle eggs, instead of an individual with the highest bid. Every year, 10 to 15 cooperative members were selected based on a lucky draw to patrol the nesting beaches in rotation. Fishing was the main livelihood activity then, although members of the cooperative relied on turtle egg collection as a side income. Conservation efforts to incubate turtle eggs also began in the 1980s, when the government started buying back eggs from the cooperative via the egg collectors. This was further supported by SEATRU (Sea Turtle Research Unit c/o Universiti Malaysia Terengganu), who also started paying for in-situ nests at Chagar Hutang Beach in 1993 (Chan 2013). Subsequently, Mak Kepit Beach was removed from the tender list in 1998 because it 
Fig. 2. Location of the study site: (A) Map of Peninsular Malaysia indicating the location of Redang Island. (B) Map of Redang Island Marine Park indicating the turtle sanctuaries on the west and north of the island and the village in the center. Most resorts are located at the Pasir Panjang beach on the east side of the island. (C) Sampling was conducted in Redang village, the only settlement in the island. The village is located in the center, with no direct access to the turtle nesting beaches. Map adapted from Chan 2013.

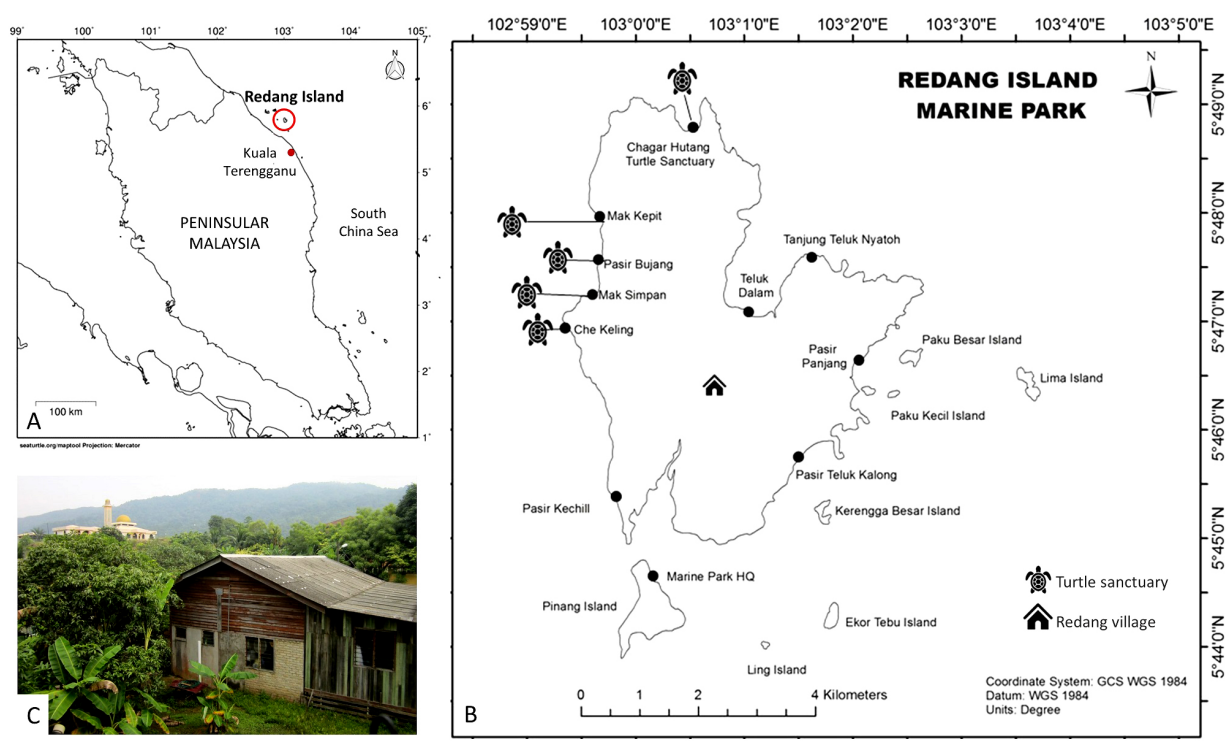

was more cost effective to hire rangers than to buy back eggs (Mohd Jani et al. 2020). In 2005, the tender system was fully abolished for all beaches on Redang Island. Two years later, five important nesting beaches were gazetted as turtle sanctuaries (Fig. 2). Turtle egg collection is prohibited from all beaches on the island and is managed by the Terengganu State Department of Fisheries (see Mohd Jani et al. 2020 for the categories of nesting beaches). Although illegal, collection occurs on the smaller beaches that are not gazetted and therefore have no surveillance, unlike in the turtle sanctuaries.

In addition to measures driven by the state, turtle conservation has been addressed by engaging with local communities through awareness raising. For example, SEATRU conducted a long-term turtle awareness program for all grade 5 (age 11) students from the Redang primary school from 1996 to 2013, with a total of 800 participants. The participants were taken to Chagar Hutang Turtle Sanctuary, where they learned about the biology and threats to sea turtles and observed nesting. At the end of this program, each student pledged to stop consuming turtle eggs (Tan 2004). The program was discontinued in 2014 on account of lack of funding.

Despite the protection of several nesting beaches and long-term awareness raising, consumption of turtle eggs continues. There are no studies on the consumer profile, motivations, and perceptions of the complex practice of turtle egg consumption in Redang Island. This study addresses the research gap by assessing the prevalence and patterns of turtle egg consumption, identifying the demographic factors influencing the practice, and understanding the local perceptions toward turtle egg consumption and conservation.

\section{METHODS}

\section{Study area}

Redang Island in the South China Sea has a land area of $25 \mathrm{~km}^{2}$. The island is located $45 \mathrm{~km}$ off Kuala Terengganu at the northeast coast of Peninsular Malaysia and belongs to the Terengganu State (Fig. 2). Redang is a popular tourist destination with diverse marine life. The island hosts Peninsular Malaysia's largest green turtle nesting population and a small number of nesting hawksbill turtles (Chan 2006). Nesting occurs throughout the year, with about 2400 nests yearly (Terengganu State Department of Fisheries, unpublished data) and peaks from May to August (Wenceslau 2017).

The Redang Island archipelago was declared as a Marine Park in 1994, protecting 2 nautical miles of marine waters surrounding the archipelago (Salleh et al. 2010). There are turtle nesting beaches around the island, five of which are declared as turtle sanctuaries (since 2007) and lie to the north (Fig. 2). Kampung Baru Pulau Redang (Redang village hereafter), the sole village in the center of the island, has approximately 2150 residents and 232 households.

Prior to the establishment of the Marine Park in 1994, 90\% of the locals were fishermen (Ibrahim 2007). Over the years, locals have shifted to the tourism sector as the main source of economic activity. The establishment of the marine park prohibited fishing and promoted tourism development. Although the islanders claimed that their request for traditional access to the marine park waters was ignored in the design of the Marine Park, Hill (2017) found that islanders working in the tourism industry supported the protection measures and demanded stricter enforcement. As 
more local livelihoods come to depend on tourism, islanders increasingly see the value in protecting the marine ecosystem (Hill 2017). Some locals continue to fish, particularly during the monsoon when tourism activities stop (Yeo et al. 2007). The current inflow of tourists visiting Redang far exceeds the local population. It has grown from 1000 annual visitors in the early 1990s (Yacob et al. 2007) to 184,043 in 2017 (Terengganu State Department of Marine Park, unpublished data). Tourism is seasonal, and the resorts remain closed during the northeast monsoon (November to March). Tourism reaches its peak between the months of May and August (Ahmad 2009), coinciding with the peak turtle nesting season.

\section{Data collection}

We conducted 73 interviews between July and September 2017 in 73 households in Redang village $32 \%$ of all households in Redang). The households were sampled opportunistically, between 9:00 AM and 6:00 PM, by knocking on the doors or approaching houses with member(s) sitting outside. The broad time window was convenient for us to reach potential respondents because employed locals mainly worked in shifts in the tourism sector. Moreover, most respondents were available with fewer distractions because it coincided with children being at school. Respondents included any adult household member over 18 years of age and not necessarily the head of the household.

We used semi-structured interviews to gather data on the respondents' demographic information, egg consumption status, and perceptions of sea turtle egg consumption and conservation in Redang (see interview guide in Appendix 2). The interviews were conducted in Malay and lasted between 28 minutes and 120 minutes, depending on the respondents' answering style, time availability, and knowledge on the topic.

Three people constituted the field team. The primary researcher, foreign to Malaysia (from the Global South), did not speak Malay. Additional members included a local $\mathrm{PhD}$ researcher from Universiti Malaysia Terengganu (UMT) and a Malay translator, who were well connected in Redang and spoke the local language. This helped minimize miscommunication and established a feeling of trust during the interviews. Furthermore, unlike the clandestine nature of turtle egg consumption in some parts of the world, the practice is not illegal in the study area, making it an approachable topic for discussion. The primary researcher designed the questionnaire, observed all interviews, and conducted the data analysis and interpretation. The local UMT researcher who administered the interviews was an experienced conservation scientist who has worked with local island communities. The Malay translator took notes during the interviews and transcribed each interview. After the completion of each interview, the research team discussed the highlights. The primary researcher maintained a field journal to reflect on the interviews at the end of each working day, based on interview observations and discussions with the research team. During the stage of data analysis and interpretation, there were regular consultations with the larger research team.

Research permission was granted by the Ethical Biosecurity Committee of UMT (Ref: SEATRU/RES/18/43). Before each interview, we explained the research aims and data protection regulations, assuring anonymity and confidentiality to all respondents. Participation was voluntary and respondents could withhold any information that they did not wish to share. Prior permission to record the interviews was taken in writing, because it was important to reaffirm the translations.

We transcribed and summarized the interview data. Additionally, we numerically coded the answers for structured questions (wherever possible) into a data sheet to carry out quantitative statistical analysis (Newing et al. 2011).

\section{Data analysis}

Prevalence, patterns, and perceptions of sea turtle egg consumption

We used a mixed-method approach of quantitative and qualitative analyses to explain the prevalence, patterns, and perceptions of turtle egg consumption and conservation. Using descriptive analyses, we calculated response percentages to get an overall understanding of the discourse. To support the data qualitatively, we used respondent quotes to explain the trends observed in egg consumption and general perceptions of sea turtle conservation.

\section{Demographic factors influencing sea turtle egg consumption}

Binary logistic regression models were built to determine the demographic factors influencing the respondents' egg consumption. Turtle egg consumption was the binary dependent variable $(0=$ does not consume eggs, $1=$ consumes eggs $)$. Five predictor variables related to the respondents' demographics were included: age, education level, occupation type and status, place of origin, and gender. These predictors were selected based on previous wildlife consumption studies, preliminary data exploration, and observations during the interviews (see Table 1 for a summary of the hypothesized effects of each predictor). We standardized the predictor variable "age." We removed the occupation "fishing" because of a small sample size of only six

Table 1. Description of the demographic predictor variables and their hypothesized effect on sea turtle egg consumption. The variables were selected based on previous studies, preliminary data exploration, and observations during the interviews.

\begin{tabular}{|c|c|c|}
\hline $\begin{array}{l}\text { Demographic } \\
\text { characteristics or predictor } \\
\text { variables in this study }\end{array}$ & Hypothesized predictor effect & References \\
\hline $\begin{array}{l}\text { Age of the individuals (in } \\
\text { years) }\end{array}$ & $\begin{array}{l}\text { Older people are more likely } \\
\text { to consume turtle eggs }\end{array}$ & $\begin{array}{l}\text { TRAFFIC } \\
\text { Southeast Asia } \\
\text { (2009), Abd } \\
\text { Mutalib et al. } \\
\text { (2013), Morsello et } \\
\text { al. (2015) }\end{array}$ \\
\hline $\begin{array}{l}\text { Education level } \\
(0=\text { no formal education, } \\
1=\text { primary level, } 2= \\
\text { secondary level and above })\end{array}$ & $\begin{array}{l}\text { Members with decreased } \\
\text { education are more likely to } \\
\text { consume turtle eggs }\end{array}$ & $\begin{array}{l}\text { Fungo et al. (2016), } \\
\text { Davis et al. (2020) }\end{array}$ \\
\hline $\begin{array}{l}\text { Occupation type and } \\
\text { status } \\
\text { (tourism, fishing, local } \\
\text { business, government, } \\
\text { unemployed or retired) }\end{array}$ & $\begin{array}{l}\text { Those employed in tourism } \\
\text { are less likely to consume } \\
\text { turtle eggs. Those employed } \\
\text { in fishing are more likely to } \\
\text { consume turtle eggs }\end{array}$ & Chaves et al. (2017) \\
\hline $\begin{array}{l}\text { Place of origin }(1= \\
\text { Redang, } 0=\text { mainland })\end{array}$ & $\begin{array}{l}\text { Members who are native to } \\
\text { Redang Island are more likely } \\
\text { to consume turtle eggs }\end{array}$ & Fungo et al. (2016) \\
\hline $\begin{array}{l}\text { Gender } \\
(1=\text { male, } 0=\text { female })\end{array}$ & $\begin{array}{l}\text { Men are more likely to } \\
\text { consume turtle eggs }\end{array}$ & $\begin{array}{l}\text { TRAFFIC } \\
\text { Southeast Asia } \\
(2009)\end{array}$ \\
\hline
\end{tabular}


fishers. Multicollinearity was checked by calculating the variance inflation factors (VIF) from the "car" package (Fox and Weisberg 2011). There were no variables with a VIF higher than 3 and thus no variables were dropped from the models (Harisson et al. 2018). The odds ratios (OR) were calculated for each predictor. An OR measures how many times bigger the odds of a given outcome is for one value of a predictor variable, after controlling for other predictors. OR values greater than 1 indicate that as the predictor increases, the odds of the outcome increases. The Wald's chisquared test was used to assess the significance of predictor variables. The overall significance of the models were assessed using the analysis of variance (ANOVA) function, which compares the global model to a null model by using a chi-square test. If the resulting chi-square value is significant, it indicates that the model fits the data. The built models were then ranked and compared using Akaike's information criterion (AIC). Lower AIC values indicate models with higher predictive power (Burnham and Anderson 2002). Model 1, with the lowest AIC value was chosen. Significant differences are reported at the alpha level of $\alpha<0.05$. Statistical analyses were conducted using $\mathrm{R}$ version 3.5.1 (R Core Team 2018). We used the "ggplot2" package to visualize data (Wickham 2016).

\section{Demographic factors influencing perceptions of sea turtle conservation}

The relationship between demographic variables and perceptions were assessed using binary logistic regression and chi-square tests. We analyzed the following respondent perceptions with quantitative data: belief in medicinal properties of turtle eggs $(0=$ does not believe in medicinal properties, $1=$ believes in medicinal properties), impact of the protection measures on livelihood $(0=$ did not affect livelihood, $1=$ affected livelihood negatively), trends in sea turtle population (same, decreasing, increasing, not sure), threat status (threatened, not threatened), and importance of sea turtles (important for tourism, not sure, no answer). For the perception variables with binary data, we built models using logistic regression, wherein belief in medicinal properties of turtle eggs (Model 2) and the perceived impact of protection measures on the respondents' livelihood (Model 3) were the dependent variables, respectively. Five predictor variables related to the respondents' demographics were included: age, education level, occupation type and status, place of origin, and gender. We selected the same demographic variables as those mentioned in Table 1 . We analyzed the models following the same procedure as described in the previous section. For the questions that did not have binary responses, i.e., those related to trends in sea turtle population, threat status, and importance of sea turtles, we used chi-square tests to analyze the frequency of nominal data according to demographics. When expected chi-square values were below 5, we used Fisher's exact test to test proportions.

Respondent perceptions influencing sea turtle egg consumption We built one binary logistic regression model (Model 4) to assess the relationship between respondent perceptions and their turtle egg consumption. Turtle egg consumption was the binary dependent variable $(0=$ does not consume eggs, $1=$ consumes eggs). All the perceptions with quantitative data were included as predictors: belief in medicinal properties of turtle eggs, trends in abundance of sea turtles, threat status of turtles, impact of protection status on livelihood, and importance of sea turtles. The sample size differed for this analysis $(n=44)$ because of "not available" (NA) data. We analyzed the model following the same procedure as described in the previous sections.

\section{RESULTS}

\section{Respondent profiles}

Respondents were between 20 and 80 years (mean \pm SD $=48$ \pm 14.5 years). There were marginally more females $(53 \%)$ than males $(47 \%)$. The majority were native to Redang Island $(80 \%)$. Almost all respondents had received formal education (93\%). A larger percentage of respondents were employed $(69 \%)$ and the main occupations were tourism $(26 \%)$, fishing $(12 \%)$, local business (44\%), and government (18\%). A few respondents had attended the turtle awareness program (13\%). A detailed report on respondent profiles and their corresponding egg consumption frequencies is presented in Table 2 .

\section{Prevalence and patterns of sea turtle egg consumption}

Of the 73 respondents, 44 individuals still consumed turtle eggs $(60 \%), 25$ had stopped consuming eggs $(34 \%)$, and 4 had never eaten eggs $(6 \%)$. All respondents reported a decrease in egg consumption in recent years, mainly on account of the protection of beaches and high price of eggs (Table 3). Eight out of 10 respondents who attended the awareness program (between the ages 21 to 34 years), had completely stopped consuming eggs because of the pledge. Some quotes related to the reasons for decreasing egg consumption are presented in Table 3.

Respondents stated that the frequency of egg consumption depended on the availability of eggs; of respondents who consumed eggs, $70 \%$ gave an estimate of once or twice a year. The remaining $30 \%$ did not answer this question. Turtle eggs were sourced from sellers in Redang or mainland, presented as a gift or self-collected either by the respondent or another household member (Fig. 3). The eggs were consumed as a delicacy, cultural food, and traditional medicine. They were consumed raw, boiled, or pickled (preserved for a long duration).

Fig. 3. Sources of turtle eggs.

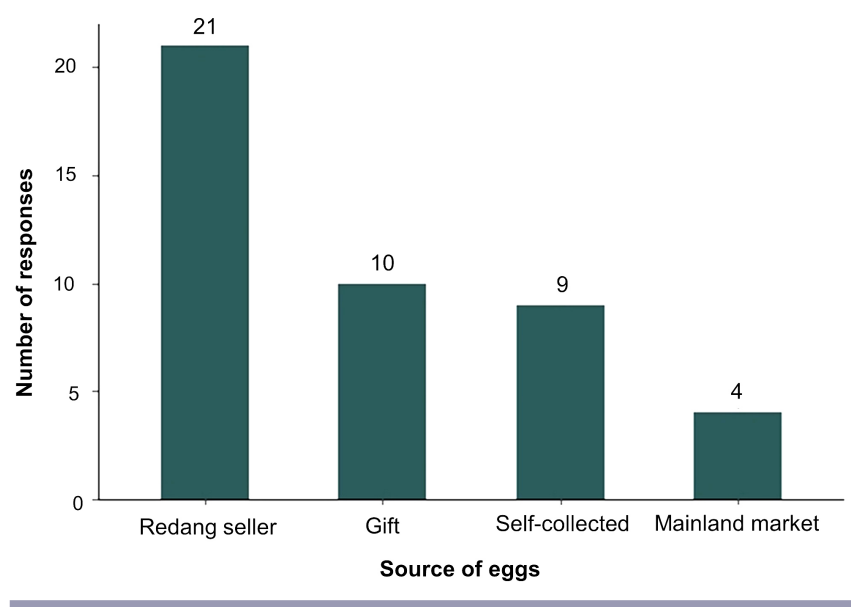

Demographic factors influencing sea turtle egg consumption

Binary logistic regression models were run with age, occupation, education level, gender, and place of origin as the predictors and egg consumption as the response. Education level and the age of 
Table 2. Demographic characteristics of the surveyed respondents $(n=73)$ in Kampung Baru (Redang Village). The values relate to the number of observations and egg consumer profiles (represented as \% frequency).

\begin{tabular}{|c|c|c|c|}
\hline Respondent characteristics & Sample size & $\begin{array}{l}\text { Number of turtle egg consumers } \\
\text { (Frequency) }\end{array}$ & $\%$ Frequency of turtle egg consumers \\
\hline Number of respondents surveyed & 73 & 44 & 60 \\
\hline \multicolumn{4}{|l|}{ Gender: } \\
\hline Male & 34 & 21 & 61 \\
\hline Female & 39 & 23 & 59 \\
\hline \multicolumn{4}{|l|}{ Place of origin: } \\
\hline Redang & 58 & 35 & 60 \\
\hline Mainland & 15 & 9 & 60 \\
\hline \multicolumn{4}{|l|}{ Age category: } \\
\hline 18 to 35 & 19 & 8 & 42 \\
\hline 36 to 53 & 29 & 14 & 48 \\
\hline 54 and above & 25 & 22 & 88 \\
\hline \multicolumn{4}{|l|}{ Education level: } \\
\hline No school & 4 & 4 & 100 \\
\hline Primary level education & 34 & 27 & 79 \\
\hline Secondary level and higher & 35 & 13 & 37 \\
\hline \multicolumn{4}{|l|}{ Financial status: } \\
\hline Earning member & 50 & 29 & 58 \\
\hline Dependent member & 23 & 15 & 65 \\
\hline \multicolumn{4}{|l|}{ Occupation status and type: } \\
\hline Tourism & 13 & 1 & 7 \\
\hline Fishing & 6 & 6 & 100 \\
\hline Local business & 22 & 16 & 72 \\
\hline Government & 9 & 6 & 66 \\
\hline Unemployed and retired & 23 & 15 & 65 \\
\hline \multicolumn{4}{|l|}{ Attendance at awareness program: } \\
\hline Attended the awareness program & 10 & 2 & 20 \\
\hline Did not attend the awareness program & 63 & 42 & 66 \\
\hline \multicolumn{4}{|l|}{ Involvement in tender system: } \\
\hline Participated in tender system & 40 & 30 & 75 \\
\hline Did not participate in tender system & 33 & 14 & 42 \\
\hline
\end{tabular}

respondents were highly negatively correlated (Spearman correlation: $\rho=-0.68$, df $=71, p<0.001$, Fig. A3.1). However, given that the VIF values of all variables were below 3 , we included education level and age in the same model. Using the AIC approach, we selected the best model with the lowest AIC (Table 4). Model 1 indicates that egg consumption significantly differed based on the education level of respondents $(\beta=-1.52, \mathrm{SE}=0.73$, $\mathrm{p}<0.05)$. With increasing education level, the likelihood of egg consumption decreases. Among those who completed secondary level or higher education $(n=35), 13$ respondents consumed turtle eggs $(37 \%)$. Whereas, $79 \%$ of the respondents with primary level education $(n=34)$ and all four respondents with no formal education consumed eggs (Table 2). Those employed in the tourism sector were significantly less likely to consume turtle eggs $(\beta=-3.17, \mathrm{SE}=1.31, \mathrm{p}<0.05)$.

\section{Respondent perceptions}

Beliefs in the medicinal properties of eggs

Various beliefs on the medicinal properties of eggs were mentioned (Fig. 4). However, nine respondents mentioned that turtle eggs are high in cholesterol, a negative health effect.
Fig. 4. Traditional medicinal beliefs and other health effects associated with turtle egg consumption.

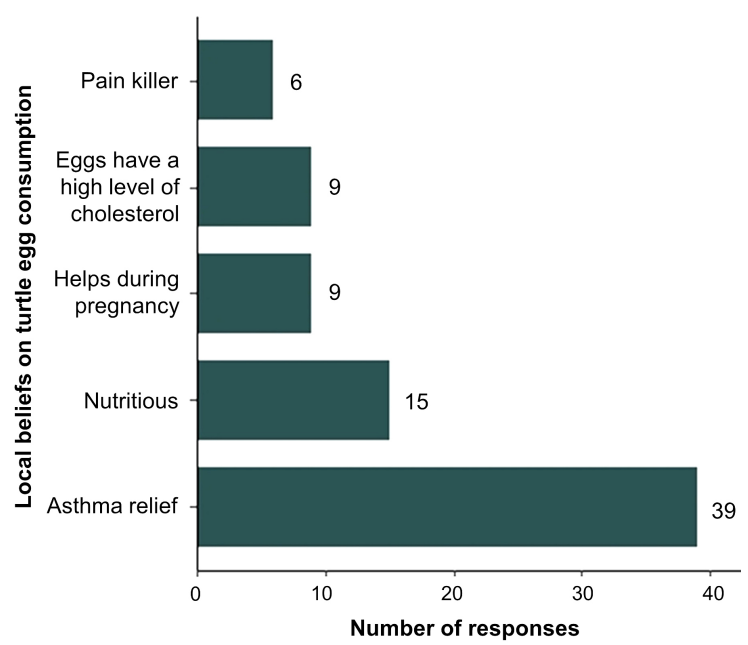


Table 3. Reasons for the decrease in turtle egg consumption stated by the respondents, with illustrative example quotes.

\begin{tabular}{|c|c|c|}
\hline $\begin{array}{l}\text { Reasons for decreasing turtle egg } \\
\text { consumption }\end{array}$ & $\begin{array}{l}\text { Number of } \\
\text { responses }(n)\end{array}$ & Relevant respondent quotes \\
\hline Protection of nesting beaches & 36 & $\begin{array}{l}\text { "In the } 90 \text { s, I ate eggs often during the nesting season, but now I eat them rarely since they are not } \\
\text { easily available due to the protection." (Respondent: } 65 \text { years, man, unemployed) } \\
\text { "In the } 70 \text { s and } 80 \text { s the egg collectors used to collect all the eggs from the nests on the beach. If that } \\
\text { was continued, we wouldn't be seeing turtles now." (Respondent: } 55 \text { years, man, works in the } \\
\text { government) }\end{array}$ \\
\hline Turtle eggs are expensive & 32 & $\begin{array}{l}\text { "I paid } 80 \text { cents to } 1 \text { MYR for an egg in the } 1990 \text { s and now it is around } 3 \text { to } 4 \text { MYR." (Respondent: } \\
63 \text { years, man, fisher) } \\
\text { "Generally, the locals buy } 2 \text { to } 3 \text { eggs per person because the price of eggs is expensive for us." } \\
\text { (Respondent: } 64 \text { years, woman, works in a local grocery shop) }\end{array}$ \\
\hline Dislike the taste of turtle eggs & 9 & $\begin{array}{l}\text { "I have tried turtle eggs once, but I did not like it. It is very slimy, and I felt strange after eating it." } \\
\text { (Respondent: } 20 \text { years, woman, works in a grocery shop) } \\
\text { "I have been eating turtle eggs since I was a child and I crave it sometimes, but my children do not } \\
\text { like the taste of turtle eggs." (Respondent: } 52 \text { years, man, works in a local restaurant) }\end{array}$ \\
\hline Awareness program & 8 & $\begin{array}{l}\text { "The sea turtle camp was very good. I saw my first sea turtle nesting there. At the end of the camp } \\
\text { we promised to not eat turtle eggs and I still follow it." (Respondent: } 27 \text { years, man, works in a } \\
\text { resort) } \\
\text { "The pledge taken by the children at the awareness program was very effective. In my opinion } 80 \% \\
\text { of those who went for this program don't eat eggs anymore. But there are still some who eat eggs } \\
\text { after taking the pledge." (Respondent: } 32 \text { years, woman, school teacher in Redang primary school) } \\
\text { "My children did not allow my husband to eat turtle eggs after attending the awareness program." } \\
\text { (Respondent: } 54 \text { years, woman, unemployed) }\end{array}$ \\
\hline Health reasons & 2 & $\begin{array}{l}\text { "Turtle eggs have a high cholesterol level, more than chicken eggs." (Respondent: } 47 \text { years, woman, } \\
\text { unemployed) }\end{array}$ \\
\hline
\end{tabular}

The binary logistic regression models were run with age, occupation, education level, gender, and place of origin as predictors, and belief in the medicinal properties of turtle eggs as a binary response (Table 5). Education level and age were highly negatively correlated (Fig. A3.1). Because the VIF values of all variables were below 3 , we included education level and age in the same model. Model 2 indicates that with increasing education level, the likelihood of believing in the medicinal properties decreases $(\beta=-1.27, \mathrm{SE}=0.73, \mathrm{p}<0.05)$.

Perceptions of trends in sea turtle population

A total of $71 \%$ respondents had observed sea turtle nesting; these respondents were more likely to be men $\left(\chi^{2}=16.2\right.$, df $=1, p<$ $0.001)$. A high percentage of respondents perceived a change in abundance of turtles in recent years $(70 \%)$. The changing trend in sea turtle abundance was classified as follows: decreasing $(61 \%)$, increasing $(9 \%)$, or stable $(6 \%)$, with the remaining respondents stating they did not know. The 16 respondents who did not know whether there was any change in abundance were all women. Fisher's exact test showed that perceiving a change in abundance was more likely in men $(\mathrm{p}<0.001)$ and did not vary by other demographic variables (age, education level, occupation, and place of origin).

\section{Perceptions of the protection status of nesting beaches}

A total of $92 \%$ of the respondents stated that protection was good. A majority (67\%) suggested that turtles would go extinct without protection. The views on protection did not significantly vary based on any of the demographic variables. Some stated that initiation of protection affected their livelihood negatively (19\%); these respondents had all been egg collectors. Model 3 shows that men $(\beta=2.23, \mathrm{SE}=0.97, \mathrm{p}<0.05)$, those who were native to Redang $(\beta=2.42, \mathrm{SE}=1.51, \mathrm{p}<0.05)$, and older people $(\beta=$ $0.06, \mathrm{SE}=0.04, \mathrm{p}<0.05)$ were more likely to have been affected negatively (Table 6). Those who claimed that they were not affected by the protection measures said that turtle egg collection was a side income $(19 \%)$, tourism was an alternative $(17 \%)$, or they were not directly dependent on sea turtles for livelihood $(32 \%)$. The remaining interviewees did not answer the question.

\section{Perceptions of threats to sea turtles}

Respondents perceived the threat status of sea turtles in Redang Island to be threatened $(35 \%)$ or not threatened (37\%), with the remaining $28 \%$ saying they did not know the threat status. The chi-square tests indicate that perceptions of the threat status did not vary by demographics (Appendix 4). Threats related to fisheries operations were the most frequently named threat by respondents (Fig. 5).

Fig. 5. Respondent perceptions of the threats to sea turtles.

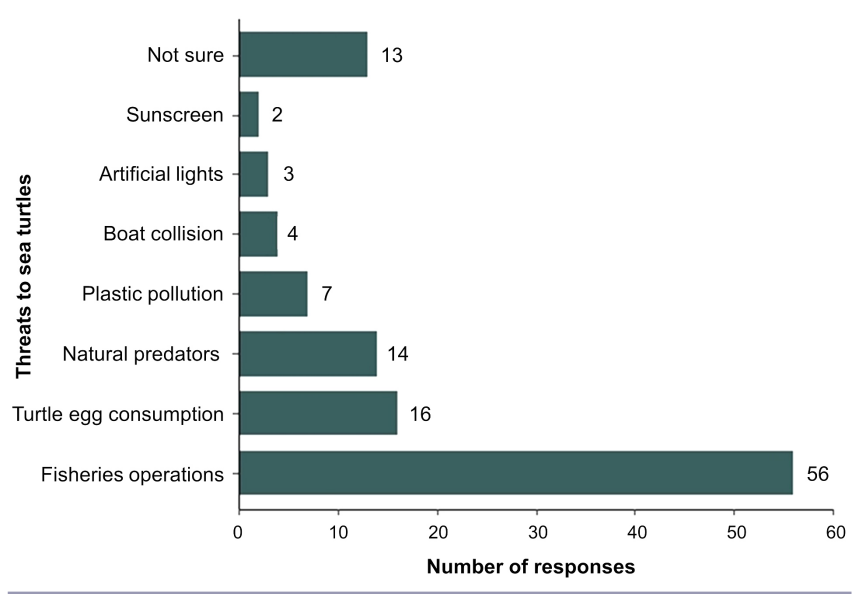


Table 4. Results of the logistic regression model that explains the demographic factors influencing the respondents' turtle egg consumption $(n=73)$. Values indicate the coefficient estimates $(\beta) \pm$ standard errors of estimates $(\mathrm{SE})$, model deviance and the associated degrees of freedom (df), and p-value. The Akaike's information criterion (AIC) of the model is also presented.

\begin{tabular}{|c|c|c|c|c|}
\hline \multirow[t]{2}{*}{ Predictor variable } & \multicolumn{4}{|c|}{ Model 1 (relationship between respondent demographics and turtle egg consumption) } \\
\hline & Estimate $(\beta) \pm \mathrm{SE}$ & Lower CI & Odds Ratio (OR) & Upper CI \\
\hline (Intercept) & $4.39 \pm 2.96$ & 0.28 & 8.06 & 13.1 \\
\hline Age (years) & $0.007 \pm 0.02$ & 1.00 & 1.00 & 1.09 \\
\hline Education level & $-1.52 \pm 0.73 *$ & 0.04 & 0.21 & 0.85 \\
\hline Occupation (fishing) & NA & NA & NA & NA \\
\hline Occupation (local business) & $0.14 \pm 0.91$ & 0.17 & 1.15 & 6.92 \\
\hline Occupation (tourism) & $-3.17 \pm 1.31 *$ & 0.001 & 0.04 & 0.41 \\
\hline Occupation (unemployed) & $-0.43 \pm 0.92$ & 0.09 & 0.64 & 3.77 \\
\hline Model deviance & \multirow{2}{*}{\multicolumn{4}{|c|}{$\begin{array}{c}27.03(\mathrm{df}=5)^{* * *} \\
76.63\end{array}$}} \\
\hline Full model AIC & & & & \\
\hline
\end{tabular}

$* \mathrm{p}<0.05 ; * \mathrm{p}<0.01 ; * * \mathrm{p}<0.001$

Table 5. Results of the logistic regression model that explains the influence of respondents' age on the belief in medicinal properties of turtle eggs $(\mathrm{n}=73)$. Values indicate the coefficient estimates $(\beta) \pm$ standard errors of estimates (SE), model deviance and the associated degrees of freedom (df), and p-value.

\begin{tabular}{|c|c|c|c|c|}
\hline \multirow[t]{2}{*}{ Predictor variable } & \multicolumn{4}{|c|}{$\begin{array}{c}\text { Model } 2 \text { (relationship between respondent } \\
\text { demographics and belief in the medicinal properties } \\
\text { of turtle eggs) }\end{array}$} \\
\hline & $\begin{array}{l}\text { Estimate }(\beta) \pm \\
\text { SE }\end{array}$ & $\begin{array}{l}\text { Lower } \\
\text { CI }\end{array}$ & $\begin{array}{l}\text { Odds Ratio } \\
\text { (OR) }\end{array}$ & $\begin{array}{l}\text { Upper } \\
\text { CI }\end{array}$ \\
\hline (Intercept) & $0.06 \pm 3.49$ & 0.001 & 1.07 & 4.86 \\
\hline Age (years) & $0.03 \pm 0.03$ & 1.02 & 1.03 & 1.14 \\
\hline Education level & $-1.27 \pm 0.73^{*}$ & 0.04 & 0.27 & 1.08 \\
\hline Occupation (fishing) & NA & NA & NA & NA \\
\hline $\begin{array}{l}\text { Occupation (local } \\
\text { business) }\end{array}$ & $2.15 \pm 1.33$ & 0.03 & 0.56 & 7.24 \\
\hline Occupation (tourism) & $-1.35 \pm 1.98$ & 0.09 & 0.36 & 4.68 \\
\hline $\begin{array}{l}\text { Occupation } \\
\text { (unemployed) }\end{array}$ & $2.52 \pm 1.33$ & 0.02 & 0.57 & 7.00 \\
\hline $\begin{array}{l}\text { Place of origin } \\
\text { (Redang) }\end{array}$ & $-0.65 \pm 0.77$ & 0.21 & 0.52 & 3.23 \\
\hline Gender (male) & $-0.45 \pm 0.77$ & 0.14 & 0.66 & 2.92 \\
\hline Model deviance & \multirow{2}{*}{\multicolumn{4}{|c|}{$22.36(\mathrm{df}=7)^{* *}$}} \\
\hline Full model AIC & & & & \\
\hline
\end{tabular}

Perceptions of the importance of sea turtles

A total of $70 \%$ stated that sea turtles were important for tourism in Redang, $16 \%$ did not know if they were important, and $13 \%$ did not answer. Fisher's exact test showed that younger people were more likely to perceive the importance of turtles for tourism $(p<0.001)$. All the respondents employed in the tourism sector highlighted the importance of turtles for tourism.

\section{Respondent perceptions influencing sea turtle egg consumption}

The binary logistic regression model was run with five predictor variables: beliefs in the medicinal properties of eggs, perception of trends in turtle population, perceptions of protection status of nesting beaches, perception of threats to turtles, and perception of importance of turtles were the five predictors, and egg consumption was the response. Model 4 indicates that egg consumption significantly differed based on the perceptions of
Table 6. Results of the logistic regression model that explains the influence of respondents' demographics on the perceived negative effect of the protection status on their livelihood $(n=73)$. Values indicate the coefficient estimates $(\beta) \pm$ standard errors of estimates (SE), model deviance and the associated degrees of freedom (df), and p-value.

\begin{tabular}{|c|c|c|c|c|}
\hline \multirow[t]{2}{*}{ Predictor variable } & \multicolumn{4}{|c|}{$\begin{array}{l}\text { Model } 3 \text { (relationship between respondent } \\
\text { demographics and perceived negative effect of } \\
\text { protection on their livelihood) }\end{array}$} \\
\hline & $\begin{array}{c}\text { Estimate }(\beta) \pm \\
\text { SE }\end{array}$ & $\begin{array}{c}\text { Lower } \\
\text { CI }\end{array}$ & $\begin{array}{l}\text { Odds Ratio } \\
\text { (OR) }\end{array}$ & $\begin{array}{l}\text { Upper } \\
\text { CI }\end{array}$ \\
\hline (Intercept) & $-6.41 \pm 1.82 *$ & 0.0001 & 0.009 & 0.06 \\
\hline Age (years) & $0.06 \pm 0.04 *$ & 0.90 & 1.07 & 1.11 \\
\hline Education level & $-0.58 \pm 0.59$ & 0.32 & 1.79 & 6.50 \\
\hline Occupation (fishing) & NA & NA & NA & NA \\
\hline $\begin{array}{l}\text { Occupation (local } \\
\text { business) }\end{array}$ & $-0.89 \pm 1.25$ & 0.02 & 0.40 & 4.62 \\
\hline Occupation (tourism) & $-1.70 \pm 1.36$ & 0.006 & 0.18 & 2.18 \\
\hline $\begin{array}{l}\text { Occupation } \\
\text { (unemployed) }\end{array}$ & $0.15 \pm 1.16$ & 0.14 & 1.16 & 8.52 \\
\hline $\begin{array}{l}\text { Place of origin } \\
\text { (Redang) }\end{array}$ & $2.42 \pm 1.51^{*}$ & 0.94 & 1.12 & 18.1 \\
\hline Gender (male) & $2.23 \pm 0.97^{*}$ & 1.51 & 6.52 & 23.1 \\
\hline Model deviance & \multirow{2}{*}{\multicolumn{4}{|c|}{$\begin{array}{c}18.94(\mathrm{df}=7)^{* *} \\
60.0\end{array}$}} \\
\hline Full model AIC & & & & \\
\hline
\end{tabular}

medicinal beliefs in turtle eggs and the threat status of turtles (Table 7). Those who believed in the medicinal properties of eggs were more likely to consume turtle eggs $(\beta=2.44, \mathrm{SE}=0.90, \mathrm{p}<$ $0.01)$. Respondents who perceived that turtles were threatened were less likely to consume turtle eggs $(\beta=-2.26, \mathrm{SE}=1.06, \mathrm{p}<$ $0.05)$.

\section{DISCUSSION}

In this study, we describe the prevalence, influencing factors, and perceptions of sea turtle egg consumption and conservation in Redang Island. Turtle egg consumption has become an infrequent practice. We found that this decrease was influenced by multiple interrelated factors, including protection measures, increased market prices, and demographic factors linked to the respondents' education level and occupation. Respondent perceptions of the 
Table 7. Results of the logistic regression model that explains the influence of respondents' perceptions on turtle egg consumption (n $=44)$. Values indicate the coefficient estimates $(\beta) \pm$ standard errors of estimates $(\mathrm{SE})$, model deviance and the associated degrees of freedom (df), and p-value.

\begin{tabular}{|c|c|c|c|c|}
\hline \multirow[t]{2}{*}{ Predictor variable } & \multicolumn{4}{|c|}{ Model 4 (relationship between respondent perceptions and turtle egg consumption) } \\
\hline & Estimate $(\beta) \pm \mathrm{SE}$ & Lower CI & Odds Ratio (OR) & Upper CI \\
\hline (Intercept) & $-0.06 \pm 1.65$ & 0.04 & 0.93 & 3.79 \\
\hline Beliefs in the medicinal properties of turtle eggs (yes) & $2.44 \pm 0.90^{* *}$ & 2.23 & 11.55 & 18.5 \\
\hline Perceived trends in turtle population (increase) & $-1.18 \pm 1.43$ & 0.01 & 0.30 & 5.2 \\
\hline Perceived trends in turtle population (same) & $-0.91 \pm 1.62$ & 0.01 & 0.40 & 13.8 \\
\hline $\begin{array}{l}\text { Perceived effect of protection status on livelihood } \\
\text { (negatively affected) }\end{array}$ & $1.02 \pm 1.20$ & 0.29 & 2.78 & 17.7 \\
\hline Perceived threat status of turtles (threatened) & $-2.26 \pm 1.06^{*}$ & 0.009 & 0.10 & 0.71 \\
\hline $\begin{array}{l}\text { Perceived importance of turtles (important for } \\
\text { tourism) }\end{array}$ & $0.51 \pm 1.43$ & 0.06 & 1.66 & 26.9 \\
\hline Model deviance & \multicolumn{4}{|c|}{$19.25(\mathrm{df}=7)^{* * *}$} \\
\hline Full model AIC & \multicolumn{4}{|c|}{46.16} \\
\hline
\end{tabular}

medicinal properties of turtle eggs and perceived threat status of turtles also influenced egg consumption. A graphical summary of this study is presented in Appendix 5.

Although $60 \%$ of the respondents still eat turtle eggs, all consumers reported a decrease in consumption in recent years. In line with findings from mainland Terengganu (TRAFFIC Southeast Asia 2009), most consumers ate turtle eggs only once or twice a year and consumption was low per sitting ( 2 to 3 eggs). Respondents mainly attributed this decrease and infrequency in consumption to the protection of nesting beaches, which has decreased the availability of turtle eggs, consequently increasing their price. Previous studies have also observed a decreasing trend in wildlife consumption because of increasing market prices (Wilkie et al. 2005, Garland and Carthy 2010, Brashares et al. 2011, TRAFFIC Southeast Asia 2009, Abd Mutalib et al. 2013). Turtle eggs have become exclusive, with consumers rarely collecting eggs themselves because of reduced access to the nesting beaches. This has led to consumers mostly relying on local egg sellers or receiving the eggs as a gift (Fig. 3).

\section{Factors influencing sea turtle egg consumption}

There is a complex interplay between the respondents' demographics, perceptions, and egg consumption. We cannot conclude with certainty what the strongest predictor of egg consumption is, because variables of demographics and perceptions were modeled separately on account of the varying sample sizes. However, we provide an overall picture of which demographics and perceptions are important and the relationships between them.

Turtle egg consumption was influenced by the respondents' education level. Respondents with lower education levels were more likely to consume turtle eggs. However, it is important to highlight the strong relationship between age and education, wherein older respondents had lower levels of education (Fig. A3.1). It is difficult to disentangle their effects on each other. Younger people had higher levels of education because access to education has improved in recent decades. Many authors have suggested that formal education is an important platform to sensitize people about the extraction, consumption, and preservation of natural resources (Hart 1997, Fungo et al. 2016,
Davis et al. 2020). Reduced access to education could similarly reduce access to jobs, which, in turn, would result in restricted income sources, culminating in increased dependence on natural resources such as turtle eggs (Madrigal-Ballestero and Jurado 2017). Tied into this argument, through anecdotal evidence we see that the long-term awareness program for children in Redang might have played a role in dissuading younger people from consuming turtle eggs (Tan 2004). Eight of the 10 respondents attending the awareness program explicitly stated that they had stopped consuming eggs because of the program (relevant quotes in Table 3). Awareness raising could be a potential variable in influencing egg consumption and should be investigated in future studies. Long-term engagement to address wildlife consumption, through innovative methods at an early age, has resulted in positive behavior change in many parts of the world (Marcovaldi and dei Marcovaldi 1999, Pêgas 2009, Kouassi et al. 2019). Moreover, as a community gets exposed to market access, improved transport, tourism, and media outreach, wildlife consumption behavior changes gradually (Morsello et al. 2015, Chaves et al. 2017, Verissimo et al. 2020).

Additionally, we found that people with lower education were also more likely to believe in the medicinal properties of eggs. Linked to this, we also found that those who believed in these medicinal properties were more likely to consume turtle eggs. Some older respondents mentioned that because access to Western medicine was limited in the past, turtle eggs were used as an alternative. Many of the older respondents reported the cultural significance of turtle eggs, mediated through the traditional medicinal beliefs and taste preferences. Turtle eggs were perceived to have therapeutic properties that were said to help asthmatics, pregnant women, and those suffering from myalgia (muscle pain; Fig. 4). In practice, turtle eggs were consumed raw or boiled and often pickled in brine to preserve them for long durations of even up to one year. Respondents preferred consuming raw eggs for better medicinal benefits. Some believed that "the first egg that is laid by the mother turtle is important for curing asthma." However, there is no scientific evidence on the medicinal properties of turtle eggs. Interestingly, some said they experienced a higher body temperature after eating a few eggs. Some respondents mentioned the uniqueness of the taste of sea turtle eggs in Redang. They 
claimed that "turtle eggs from Redang are more delicious because the sand in the Redang beaches is very soft and the yolk of the egg is thicker." Another respondent said that "when I go to the mainland market, I can make out the turtle eggs are not from Redang by looking at the color of the eggs and the type of sand on the egg." These strong cultural ties to food, especially amongst the older generation, indicate an attachment to place, which is shaped by the individual's life experiences (Raymond et al. 2010, Dickman et al. 2015). In comparison, younger people may prefer eggs less because of factors such as increasing access to other food types, changing taste preferences, increasing awareness, and higher levels of education (Garland and Carthy 2010). Moreover, the younger generation were born or grew up after the initiation of conservation measures in the 1980s (Fig. 1), which limited their access to turtle eggs; they are therefore less initiated to the practice of eating turtle eggs.

The respondents' occupation also played an important role in determining egg consumption. Because of the small sample size, we removed the six fishers from the models. All six fishers were egg consumers. The effect of fishers being more likely to consume turtle eggs could be a potential predictor. Fishers interact more closely with marine wildlife and often have more knowledge and access to marine resources (Senko et al. 2011). In the past, fishing was a traditional occupation in Redang and those who remain fishers may be less willing to change their old habits including eating traditional food (Yeo et al. 2007). Respondents employed in the tourism sector were less likely to eat turtle eggs. Consumptive users may be more likely to change their use pattern if they see direct and tangible economic benefits from tourism (Mejías-Balsalobre et al. 2021). The value of sea turtles in Redang seems to be gradually evolving to a non-consumptive use value, with many respondents (71\%), mainly younger people, recognizing their importance for local tourism. This similar shift in use values has been documented in several sites, where turtle tourism has become an important source of revenue (Campbell 2003, Pêgas 2009, Senko et al. 2011, Diamond et al. 2012, MejíasBalsalobre et al. 2021). Therefore, tourism makes sea turtles more valuable alive than consumed.

\section{Perceptions of sea turtle conservation}

Men were more likely to say they had observed sea turtle nesting and to have perceived a change in abundance in the sea turtle population. This is possibly on account of past experience with egg collection and sea-faring activities. Although data from the turtle sanctuaries in Redang indicate a gradual increase in the number of nesting turtles in recent years (Terengganu State Department of Fisheries, unpublished data), $61 \%$ of the respondents indicated a decreasing trend. Additionally, there were mixed responses on the threat status of sea turtles, which did not vary by demographics. Respondents who perceived turtles to be threatened (35\%) were less likely to consume turtle eggs (Table 7). Interestingly, perceiving a decreasing trend in turtle populations does not mean that people stop consuming eggs, because they do not perceive the decline to be threatening.

Most respondents reported fisheries operations as a serious threat to sea turtles (Fig. 5). In comparison to conservation interventions to protect beaches from turtle egg collection, measures to curb threats from fisheries in Malaysian waters are perceived as not sufficient (Rahman et al. 2018). The uncertainty in knowing about population trends and threats is linked to the lack of interactions with sea turtles (Senko et al. 2011). Prior to protection, the locals had access to all nesting beaches and could estimate the turtle nesting trends by the number of eggs they collected. Currently, non-authorized personnel have restricted access, only between 8:00 AM and 3:00 PM, to the turtle sanctuaries. Moreover, because the village is in the center of the island, there is no direct access to the main nesting beaches and thus fewer interactions with sea turtles. Distance from the nesting beach has been observed to play a key role in determining the relationship between humans and sea turtles (Senko et al. 2011).

Most respondents were aware of the regulations on turtle egg collection. Past egg collectors and men were more likely to know the law in this regard. Reactions toward the protection of nesting beaches were largely positive, with a majority of the respondents indicating that sea turtles would have gone extinct if not for the protection measures. A study in Brazil also found that the locals were positive toward conservation enforcement because they perceived declines in the population (Pêgas 2009). In some local communities, protected area establishment has led to increasing conflicts (Campbell 1998, Putra and Bailey 2007, MadrigalBallestero and Jurado 2017), because of their dependence on sea turtles for livelihood (Campbell 1998). In this study, a few respondents said they were affected negatively by the protection of beaches; these respondents were more likely to be men, those who were native to Redang, and older people. This is not surprising given that egg collection was practiced in the past and mostly by local men. However, many respondents said that protection did not affect their livelihood significantly. Turtle egg collection in the past, through the tender system, was a side income. Because it was regulated through a local cooperative, the profits were shared among all members. Some suggested that the rapid development of the tourism industry, during the same period, helped because it became the primary economic source. This complements the findings of many studies from around the world, where tourism as an economic alternative has helped minimize the direct dependence on natural resources, proving to be successful for sea turtle conservation (Troëng and Drews 2004, Pêgas 2009, Madrigal-Ballestero and Jurado 2017).

\section{CONCLUSION}

In this study we identify factors influencing turtle egg consumption. We provide a snapshot in the local context of Redang Island, an important turtle nesting site in Southeast Asia. The changing structures and processes to protect sea turtles have decreased turtle egg consumption over time. Turtle eggs have become an expensive and exclusive resource, decreasing the motivation to consume eggs. Moreover, people with higher levels of education and those employed in the tourism industry were less likely to eat turtle eggs. This is possibly on account of changing cultural beliefs and taste preferences, as well as increasing awareness. Furthermore, turtles are perceived to be important for tourism, thus catalyzing a shift from consumptive to nonconsumptive uses of sea turtles.

Through quantitative analysis, we studied the patterns of consumption including the relationships between demographics, perceptions, and consumption, setting a critical baseline for future studies. To further make sense of the complexity of the respondents' perceptions, we support the quantitative findings 
with basic qualitative information using interview quotes. Research on the cultural context of consuming turtle eggs in Redang, could be applied in the future. Questions for future investigation could cover the potential loss of cultural traditions and how is it experienced by the community, as well as the impact of the long-term awareness program on the younger population in Redang.

Our study focuses on turtle egg consumption and links to the wider interactions between humans and sea turtles. Although there is much emphasis on curbing egg consumption on land, there are other stressors such as fisheries bycatch that are poorly addressed by regulations. An evidence-based approach examining which stressors are actually driving the decline of sea turtles is required in Malaysia. Moreover, with the changing uses and the rapid growth in tourism, research and policy attention needs to be given to novel interactions between humans and sea turtles. Poorly managed tourism can severely impact sea turtle habitats and the behavior of the species. With this shift toward nonconsumptive use, education efforts should ideally be expanded to sensitize stakeholders from the tourism sector.

Responses to this article can be read online at: https://www.ecologyandsociety.org/issues/responses. php/12717

\section{Author Contributions:}

Meenakshi Poti and Seh Ling Long contributed equally to the study in terms of conceptualizing, collecting data, and writing and revising the manuscript. Meenakshi Poti coordinated and conducted the data analysis and compiled the original draft of the manuscript. Seh Ling Long coordinated and led the interviews in field. Mohd Uzair Rusli contributed to supervising, acquiring funding, and reviewing the manuscript. Jarina Mohd Jani, Jean Hugé, and Farid DahdouhGuebas are co-last authors as they contributed in equal part, in supervising and designing the study, acquiring funding, writing and reviewing the manuscript.

\section{Acknowledgments:}

First and foremost, we are grateful to the local participants of Redang Island for contributing their time and knowledge to this research. This study was supported by the Erasmus Mundus Master Course in Tropical Biodiversity and Ecosystems - TROPIMUNDO through a thesis grant and by the Sea Turtle Research Unit (SEATRU) clo Universiti Malaysia Terengganu (UMT). Published with the support of the University Foundation of Belgium. M. P. is supported by the Belgian National Science Foundation FNRS (Grant number 1139620F). F. D. G. and J. H. were supported by the Belgian National Science Foundation Project "Understanding the discursive \& practical dynamics of sustainability and its assessment in complex social-ecological systems - SASES" (FNRS-PDR, T.0262.18). This work has received research ethics approval from the Ethical Biosecurity Committee of the UMT (Ref: SEATRU/RES/18/43). We would like to thank Khaulah Zakariah for her support with fieldwork and translation of the interviews. We thank James Hagan, Thomas
Luypaert, and Mayukh Dey for helpful discussions on statistical analysis. Thanks to Shankar Poti and Bàlint Gyévai for proofreading the article. This research was in part presented at the VLIZ Marine Science Day in Bredene, Belgium (21 March, 2018) and the conference for Young Marine Researchers (YOUMARES 9- The Oceans: Our Research, Our Future) in Oldenburg, Germany (11-14 September, 2018). We thank the editors and anonymous reviewers for their valuable comments and suggestions during the review process.

\section{Data Availability:}

The datalcode that support the findings of this study are available on request from the corresponding author $M$. P. The data are not publicly available because of the sensitive information that could compromise the privacy of interviewees. Ethical approval for this research study was granted by the Ethical Biosecurity Committee of Universiti Malaysia Terengganu - UMT, Malaysia (Ref: SEATRU/RES/18/43).

\section{LITERATURE CITED}

Abd Mutalib, A. H., N. Fadzly, and R. Foo. 2013. Striking a balance between tradition and conservation: general perceptions and awareness level of local citizens regarding turtle conservation efforts based on age factors and gender. Ocean and Coastal Management 78:56-63. https://doi.org/10.1016/j.ocecoaman.2013.03.015

Ahmad, S. A. 2009. Visitors' willingness to pay for an entrance fee: a case study of marine parks in Malaysia. Dissertation. University of Glasgow, Glasgow, UK. [online] URL: http:// theses.gla.ac.uk/728/1/2009ahmadphd.pdf

Brashares, J. S., C. D. Golden, K. Z. Weinbaum, C. B. Barrett, and G. V. Okello. 2011. Economic and geographic drivers of wildlife consumption in rural Africa. Proceedings of the National Academy of Sciences 108(34):13931-13936. https://doi. org/10.1073/pnas. 1011526108

Burnham, K. P., and D. R. Anderson. 2002. Model selection and multimodel inference: a practical information-theoretic approach. 2nd edition. Springer-Verlag, New York, New York, USA.

Campbell, L. M. 1998. Use them or lose them? Conservation and the consumptive use of marine turtle eggs at Ostional, Costa Rica. Environmental Conservation 25(4):305-319. https://doi.org/10.1017/ $\underline{\mathrm{S} 0376892998000393}$

Campbell, L. M. 2003. Contemporary culture, use, and conservation of sea turtles. Pages 307-338 in P. L. Lutz, J. A. Musick, and J. Wyneken, editors. The biology of sea turtles, volume II. CRC, Boca Raton, Florida, USA.

Campbell, L. M. 2007. Local conservation practice and global discourse: a political ecology of sea turtle conservation. Annals of the Association of American Geographers 97(2):313-334. https://doi.org/10.1111/j.1467-8306.2007.00538.x

Campbell, L. M. 2010. Studying sea turtle conservation and learning about the world: insights from social science. Conservation and Society 8(1):1-4. [online] URL: https://www. jstor.org/stable/pdf/26392989.pdf 
Chan, E. H. 2006. Marine turtles in Malaysia: on the verge of extinction? Aquatic Ecosystem Health and Management 9 (2):175-184. https://doi.org/10.1080/14634980600701559

Chan, E. H. 2013. A report on the first 16 years of a long-term marine turtle conservation project in Malaysia. Asian Journal of Conservation Biology 2(2):129-135. [online] URL: http://ajcb.in/ journals/full papers dec 2013/AJCB-Vol2-No2-Chan.pdf

Chaves, W. A., D. S. Wilkie, M. C. Monroe, and K. E. Sieving. 2017. Market access and wild meat consumption in the central Amazon, Brazil. Biological Conservation 212(A):240-248. https://doi.org/10.1016/j.biocon.2017.06.013

Davis, E. O., L. Gaffi, G. Mussoni, T. Zaw, and J. A. Glikman. 2020. Insights into medicinal wildlife consumption and bear part use in Rakhine, Myanmar. Journal for Nature Conservation 58:125923. https://doi.org/10.1016/i.jnc.2020.125923

Delgado, S., and W. J. Nichols. 2005. Saving sea turtles from the ground up: awakening sea turtle conservation in northwestern Mexico. Maritime Studies 4(1):89-104. [online] URL: https:// www.marecentre.n1/mast/documents/Mast-2004p.89-104.pdf

Diamond, J., V. Blanco, and R. Duncan. 2012. Knowing sea turtles: local communities informing conservation in Koh Rong Archipelago, Cambodia. Cambodian Journal of Natural History 2012(2):131-140.

Dickman, A., P. J. Johnson, F. van Kesteren, and D. W. Macdonald. 2015. The moral basis for conservation: how is it affected by culture? Frontiers in Ecology and the Environment 13 (6):325-331. https://doi.org/10.1890/140056

Fox, J., and S. Weisberg. 2011. An R companion to applied regression. Sage, Thousand Oaks, California, USA.

Frazier, J. 2003. Prehistoric and ancient historic interactions between humans and marine turtles. Pages 1-38 in P. L. Lutz, J. A. Musick, and J. Wyneken, editors. The biology of sea turtles, volume II. CRC, Boca Raton, Florida, USA.

Fungo, R., J. H. Muyonga, M. Kabahenda, C. A. Okia, and L. Snook. 2016. Factors influencing consumption of nutrient rich forest foods in rural Cameroon. Appetite 97:176-184. https://doi. org/10.1016/j.appet.2015.12.005

Garland, K. A., and R. R. Carthy. 2010. Changing taste preferences, market demands and traditions in Pearl Lagoon, Nicaragua: a community reliant on green turtles for income and nutrition. Conservation and Society 8(1):55-72. [online] URL: https://www.jstor.org/stable/26392994

Godley, B. J., A. C. Broderick, L. P. Colman, A. Formia, M. H. Godfrey, M. Hamann, A. Nuno, L. C. M. Omeyer, A. R. Patricio, A. D. Phillott, A. F. Rees, and K. Shanker. 2020. Reflections on sea turtle conservation. Oryx 54(3):287-289. https://doi. org/10.1017/S0030605320000162

Harrison, X. A., L. Donaldson, M. E. Correa-Cano, J. Evans, D. N. Fisher, C. E. D. Goodwin, B. S. Robinson, D. J. Hodgson, and R. Inger. 2018. A brief introduction to mixed effects modelling and multi-model inference in ecology. PeerJ 6:e4794. https://doi. org/10.7717/peerj.4794
Hart, R. A. 1997. Children's participation: the theory and practice of involving young citizens in community development and environmental care. Earthscan, Abingdon, Oxfordshire, UK.

Hill, A. 2017. Blue grabbing: reviewing marine conservation in Redang Island Marine Park, Malaysia. Geoforum 79:97-100. https://doi.org/10.1016/j.geoforum.2016.12.019

Ibrahim, Y. 2007. Komuniti pulau dalam era pembangunan: terpinggir atau meminggir? (Island community in development era: are marginalised or had marginalised?) Akademika 70 (1):57-76. [online] URL: http://journalarticle.ukm.my/4300/1/ akademika65\%5B02\%5D.pdf

International Union for Conservation of Nature (IUCN). 2020. The IUCN red list of threatened species. Version 2021-2. ICUN, Cambridge, UK. [online] URL: https://www.iucnredlist.org

Kouassi, J. A. K., E. Normand, I. Koné, and C. Boesch. 2019. Bushmeat consumption and environmental awareness in rural households: a case study around Taï National Park, Côte d'Ivoire. Oryx 53(2):293-299. https://doi.org/10.1017/S0030605317000333

Liew, H. C. 2011. Tragedy of the Malaysian leatherback population: what went wrong. Pages 97-107 in P. H. Dutton, D. Squires, and M. Ahmed, editors. Conservation and sustainable management of sea turtles in the Pacific Ocean. University of Hawaii Press, Honolulu, Hawaii, USA. https://doi.

org/10.1515/9780824860196-008

Madrigal-Ballestero, R., and D. Jurado. 2017. Economic incentives, perceptions and compliance with marine turtle egg harvesting regulation in Nicaragua. Conservation and Society 15 (1):74-86. [online] URL: https://www.jstor.org/stable/26393272

Mancini, A., and V. Koch. 2009. Sea turtle consumption and black market trade in Baja California Sur, Mexico. Endangered Species Research 7(1):1-10. https://doi.org/10.3354/esr00165

Marcovaldi, M. Â., and G. G. dei Marcovaldi. 1999. Marine turtles of Brazil: the history and structure of Projeto TAMARIBAMA. Biological Conservation 91(1):35-41. https://doi. org/10.1016/S0006-3207(99)00043-9

Mazaris, A. D., G. Schofield, C. Gkazinou, V. Almpanidou, and G. C. Hays. 2017. Global sea turtle conservation successes. Science Advances 3(9):e1600730. https://doi.org/10.1126/sciadv.1600730

Mejías-Balsalobre, C., J. Restrepo, G. Borges, R. García, D. Rojas-Cañizales, H. Barrios-Garrido, and R. A. Valverde. 2021. Local community perceptions of sea turtle egg use in Tortuguero, Costa Rica. Ocean and Coastal Management 201:105423. https:// doi.org/10.1016/j.ocecoaman.2020.105423

Migraine, P. 2015. Report on illegal take and trade of marine turtles in the Indian Ocean Region. Marine Turtle Newsletter 145:27-28. [online] URL: http://www.seaturtle.org/mtn/archives/ $\underline{\mathrm{mtn} 145 / \mathrm{mtn} 145-7 . \mathrm{shtml}}$

Mohd Jani, J., M. A. Jamalludin, and S. L. Long. 2020. To ban or not to ban? Reviewing an ongoing dilemma on sea turtle egg trade in Terengganu, Malaysia. Frontiers in Marine Science 6:762. https://doi.org/10.3389/fmars.2019.00762 
Morsello, C., B. Yagüe, L. Beltreschi, N. van Vliet, C. Adams, T. Schor, M. P. Quiceno-Mesa, and D. Cruz. 2015. Cultural attitudes are stronger predictors of bushmeat consumption and preference than economic factors among urban Amazonians from Brazil and Colombia. Ecology and Society 20(4):21 https://doi.org/10.5751/ ES-07771-200421

Nada, M., and P. Casale. 2011. Sea turtle bycatch and consumption in Egypt threatens Mediterranean turtle populations. Oryx 45(1):143-149. https://doi.org/10.1017/ $\underline{\text { S0030605310001286 }}$

Newing, H., C. M. Eagle., R. K. Puri, and C. W. Watson. 2011. Conducting research in conservation: a social science perspective. Routledge, Abingdon, Oxon, UK.

Pêgas, F. D. V. 2009. Twenty-five years of sea turtle protection in Brazil: evaluating local effects. Dissertation. Texas A\&M University, College Station, Texas, USA. [online] URL: https:// oaktrust.library.tamu.edu/bitstream/handle/1969.1/ETDTAMU-2009-05-761/Pegas.pdf

Putra, K., and L. M. Bailey. 2007. Curbing the Balinese sea turtle trade. Page 30 in R. B. Mast, L. M. Bailey, and B. J. Hutchinson, editors. SWOT report volume II. State of the World's Sea Turtles, Arlington, Virginia, USA. [online] URL: https://www. seaturtlestatus.org/swot-report-vol-2

R Core Team. 2018. R: A language and environment for statistical computing. R Foundation for Statistical Computing, Vienna, Austria. [online] URL: https://www.R-project.org/

Rahman M. A. A., M. U. Rusli, N. Aziz, M. H. M. Rusli, and W. I. A. W. Talaat. 2018. An appraisal of the Malaysian legal framework in conserving the marine endangered species. Journal of Sustainability Science and Management 5:217-224. [online] URL: https://jssm.umt.edu.my/wp-content/uploads/sites/51/2019/02/ Bab-17.pdf

Raymond, C. M., G. Brown, and D. Weber. 2010. The measurement of place attachment: personal, community, and environmental connections. Journal of Environmental Psychology 30(4):422-434. https://doi.org/10.1016/j.jenvp.2010.08.002

Salleh, N. H. M., R. Othman, and N. F. A. Harun. 2010. The impact of marine park gazettement to local community sustainable livelihoods: a case study of Redang and Tioman Islands. MPRA Paper 22680, University Library of Munich, Munich, Germany. [online] URL: https://mpra.ub.unimuenchen.de/22680/1/The_Impact_of_Marine_Park_Gazettement. pdf

Sardeshpande, M., and D. MacMillan. 2019. Sea turtles support sustainable livelihoods at Ostional, Costa Rica. Oryx 53(1):81-91. https://doi.org/10.1017/S0030605317001855

Senko, J., A. J. Schneller, J. Solis, F. Ollervides, and W. J. Nichols. 2011. People helping turtles, turtles helping people: understanding resident attitudes towards sea turtle conservation and opportunities for enhanced community participation in Bahia Magdalena, Mexico. Ocean and Coastal Management 54 (2):148-157. https://doi.org/10.1016/j.ocecoaman.2010.10.030

Shanker, K., and N. J. Pilcher. 2003. Marine turtle conservation in South and Southeast Asia: hopeless cause or cause for hope.
Marine Turtle Newsletter 100:43-51. [online] URL: http:// seaturtle.org/mtn/archives/mtn100/mtn100p43.shtml

Siow, K. T., and E. O. Moll. 1982. Status and conservation of estuarine and sea turtles in West Malaysian waters. Pages 339-347 in K. A. Bjorndal, editor. Biology and conservation of sea turtles. Proceedings of the World Conference on Sea Turtle Conservation. Smithsonian Institution, Washington, D.C., USA.

Tan, K. C. 2004. Stop eating eggs? What children on two islands in Malaysia think about sea turtles as an endangered species. Dissertation. Lund University, Lund, Sweden. [online] URL: https://www.lumes.lu.se/sites/lumes.lu.se/files/tan_kien_chun.pdf

Tisdell, C., and C. Wilson. 2002. Ecotourism for the survival of sea turtles and other wildlife. Biodiversity and Conservation 11:1521-1538. https://doi.org/10.1023/A:1016833300425

TRAFFIC Southeast Asia. 2009. Survey of marine turtle egg consumption and trade in Malaysia. WWF-Malaysia, Petaling Jaya, Malaysia. [online] URL: http://repository.wwf.org.my/ technical reports/M/Marine $\% 20$ turtle $\% 20$ egg $\% 20$ consumption $\%$ 20and $\% 20$ trade $\% 20$ report March09-\%20T.pdf

Troëng, S., and C. Drews. 2004. Money talks: economic aspects of marine turtle use and conservation. WWF-International, Gland, Switzerland. [online] URL: https://wwf.panda.org/ wwf news/?153802/wwwpandaorglacmarineturtlespublications

Veríssimo, D., S. Vieira, D. Monteiro, J. Hancock, and A. Nuno. 2020. Audience research as a cornerstone of demand management interventions for illegal wildlife products: demarketing sea turtle meat and eggs. Conservation Science and Practice 2(3):e164. https://doi.org/10.1111/csp2.164

Waylen, K. A., P. J. K. McGowan, Pawi Study Group, and E. J. Milner-Gulland. 2009. Ecotourism positively affects awareness and attitudes but not conservation behaviours: a case study at Grande Riviere, Trinidad. Oryx 43(3):343-351. https://doi. org/10.1017/S0030605309000064

Wenceslau, J. F. C. 2017. 24 years of green turtle's (Chelonia mydas) conservation in Chagar Hutang Turtle Sanctuary, Redang Island, Malaysia: effects of recruitment, ENSO and EAWM. Dissertation. Vrije Universiteit Brussel, Université Libre de Bruxelles and Università degli Studi di Firenze, Brussels, Belgium; Florence, Italy.

Wickham, H. 2016. ggplot2: elegant graphics for data analysis. Springer-Verlag, New York, New York, USA. [online] URL: https://ggplot2.tidyverse.org.

Wilkie, D. S., M. Starkey, K. Abernethy, E. N. Effa, P. Telfer, and R. Godoy. 2005. Role of prices and wealth in consumer demand for bushmeat in Gabon, Central Africa. Conservation Biology 19 (1):268-274. https://doi.org/10.1111/j.1523-1739.2005.00372.x

Yacob, M. R., Y., A. Shuib, M. F. Mamat, and A. Radam. 2007. Local economic benefits of ecotourism development in Malaysia: the case of Redang Island Marine Park. International Journal of Economics and Management 1(3):363-384. [online] URL: http:// psasir.upm.edu.my/id/eprint/673/

Yeo, B. H., D. Squires, K. Ibrahim, H. Gjertsen, S. K. Syed Mohd Kamil, R. Zulkifli, T. Groves, M. C. Hong, and C. H. Tan. 2007. 
Fisher profiles and perceptions of sea turtle-fishery interactions: case study of East Coast Peninsular Malaysia. WorldFish Center, Penang, Malaysia. [online] URL: http://pubs.iclarm.net/ resource centre/Disc $\% 20$ Ser $\% 206 \% 20-020$ FINAL_oldold.pdf

Zulkifli, R., and P. Sankar. 2011. Advocacy towards holistic legal protection of turtles in Malaysia. Pages 129-130 in T. T. Jones and B. P. Wallace, editors. Proceedings of the thirty-first annual symposium on sea turtle biology and conservation. San Diego, California, USA. [online] URL: https://internationalseaturtlesociety. org/wp-content/uploads/2021/02/31-turtle.pdf 
Appendix 1. Legislation related to sea turtle conservation in Malaysia

There have been calls to ban the commercial sale of sea turtle eggs in Malaysia (NPOA 2008). However, this remains a challenge as many locals depend on sea turtles for their livelihood (Mohd Jani et al. 2020). Additionally, the legislation is complex and differs at federal and state levels. Malaysia is a federation of 13 states and the federal territory is divided into two regions, i.e. Peninsular Malaysia (with 11 states) and East Malaysia (with 2 states - Sabah and Sarawak). In Malaysia, the authority to enact law is separated between the federal and state governments through Acts of Parliament and State Legislative Assemblies respectively (Zulkifli and Sankar 2011). The Federal government does not have complete jurisdiction over matters related to sea turtles. All matters related to the regulation and monitoring of sea turtles are listed in the State Legislature (Zulkifli and Sankar 2011).

Table A1.1: In Malaysia, sea turtle related legislation operates under the international, federal and state levels. (Own synthesis based on Tan 2004, TRAFFIC Southeast Asia 2009, Zulkifli and Sankar 2011, Abd Mutalib et al. 2013).

Level

International

Federal Fisheries Act (1985)

State

(E.g. Terengganu

State)
Legislation

Convention on International Trade in Endangered Species of Wild Fauna and Flora (CITES), 1973 - Sea turtles are listed in Appendix I of CITES

Customs (Prohibition of Imports) Order (1988) and the Customs (Prohibition of Exports) Order (1988) Enact the rules of Fisheries Act (1985) Terengganu Turtles Enactment 1951 (Amended 1989)
Aspects that are prohibited

International trade of sea turtles and their products

Illegal trade, capture, killing of sea turtles

Nesting disturbance or physical injuries inflicted

Bans the import and export of sea turtles

Killing of sea turtles

Removing or destroying eggs without a licence - Penalties of up to $3000 \mathrm{MYR}$ and imprisonment 
Appendix 2. Interview guide on sea turtle egg consumption and conservation in Redang Island

Confidentiality Statement - All information collected in this survey is strictly confidential and will be used for research purposes only.

A. Date of the interview and House number

B. Respondent details

1. Gender $(0=$ Female, $1=$ Male $)$

2. Age (in years)

3. Place of origin $(0=$ Mainland, $1=$ Redang $)$

4. Number of years in Redang

5. Does he/she have a job $(1=$ Yes, $2=$ No, $3=$ Temporary, $4=$ Permanent, $5=$ Retired $)$

6. Main economic activity

7. Additional economic activities

8. Past economic activity

9. Tender system involvement

10. Employment status in his/her main economic activity $(1=$ Employee, $2=$ Employer, $3=$ Own account worker, 4 = Unpaid family worker (contributing family worker), $5=$ Other (specify))

11. Has he/she ever attended school? $(0=$ No, $1=$ Yes $)$

12. What level of education has he/she completed?

C. Turtle egg consumption status

1. Do you consume turtle eggs? (If No, proceed to C. 10)

2. When was the last time you consumed turtle eggs?

3. How often do you eat turtle eggs?

4. How many turtle eggs do you eat at a time?

5. Is there a specific occasion to eat turtle eggs?

6. Where do you source the eggs from? $(1=$ Self-collection, $2=$ Buy them from a local seller, $3=$ Mainland market, $4=$ Received it as a present, $5=$ Others (specify))

7. Which beaches are the eggs collected from?

8. How much do you pay per turtle egg?

9. Why do you eat turtle eggs?

10. When did you stop eating turtle eggs?

11 . Why did you stop eating turtle eggs?

12. Why don't you eat turtle eggs?

D. Respondent's general knowledge on sea turtles

1. Have you observed a change in abundance in turtles nesting in Redang? (Yes / No)

2. Have you ever observed a sea turtle nesting in Redang? (Yes / No)

3. Is the abundance of sea turtle nesting increasing or decreasing in Redang?

4. Have you learnt about sea turtles in your school? (Yes / No)

5. Have you attended the SEATRU awareness program? (Yes / No)

6. Are there any beliefs about turtle eggs in Redang Island?

7. What are the beliefs you are aware of in Redang Island? And do you believe in any?

8. Does any member of your family depend on turtle eggs for your income?

9. In the past did you/ anyone from the house depend on turtle eggs for your livelihood? 
E. Respondent perceptions

1. Is turtle egg consumption legal or illegal in Redang Island?

2. What are your views on turtle egg consumption?

3. What do you think about the turtle sanctuary protection status of Redang Island?

4. Has the protection affected you in any way? (If yes, how)

5. What do you think the main threats to sea turtles are?

6. Do you think turtle egg consumption impacts the sea turtle population?

7. Are turtles important to Redang? (If yes, why) 
Appendix 3. Relationship between respondents' education level and age

The respondents' education level and age were highly negatively correlated (Spearman correlation: $\rho=-0.68, \mathrm{df}=71, \mathrm{p}<0.001$, Fig. A3.1).

Fig. A3.1: The relationship between the respondents' age and education level. The thick horizontal bars in the box represent the median, bottom and top of the box are the 25th and 75th percentiles respectively. Whiskers extend until the lowest and highest value.

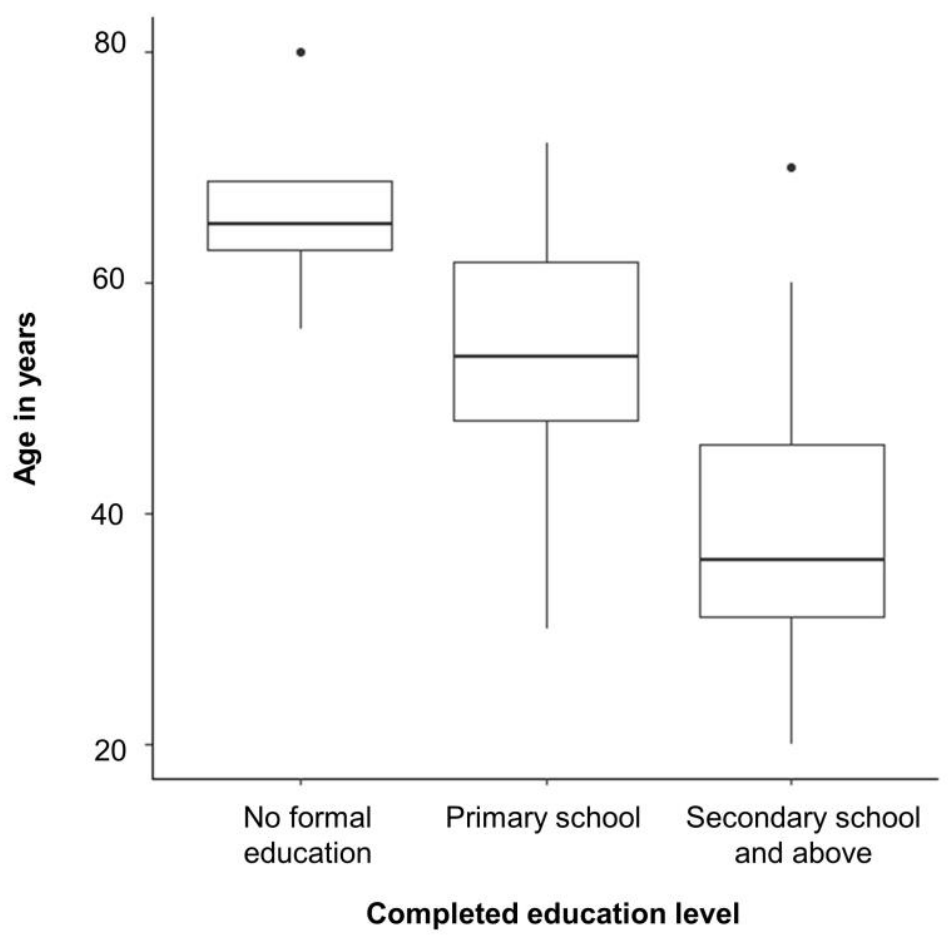


Appendix 4. Relationship between the respondents' demographics and their perception of trends in abundance of sea turtles

Table A4.1. Results of the chi-square and Fisher's exact test that explains the relationship between the respondents' demographics and their perception of trends in abundance of sea turtles. Values indicate the chi-square value $\left(\chi^{2}\right)$, associated degrees of freedom (df) and pvalue. When expected chi-square values were below five, Fisher's exact test were used.

\section{Respondent demographics}

Age category of the individuals (18 to 35,36 to 53,54 and above)

Education level

$(0=$ no formal education, $1=$ primary level,

$2=$ secondary level and above)

Occupation type and status

(tourism, fishing, local business, government, unemployed or retired)

Place of origin $(1=$ Redang, $0=$ mainland $)$

Gender

$(1=$ male, $0=$ female $)$
Perceived trend in abundance of sea turtles

(same, decreasing, increasing, don't know)

$\mathrm{p}=0.46$ (Fisher's exact test)

$\mathrm{p}=0.88$ (Fisher's exact test)

$\mathrm{p}=0.18$ (Fisher's exact test)

$\mathrm{p}=0.24$ (Fisher's exact test)

$\left(\chi^{2}=0.10, \mathrm{df}=2, \mathrm{p}=0.95\right)$ 
Appendix 5. Graphical abstract/ illustrated summary of the article
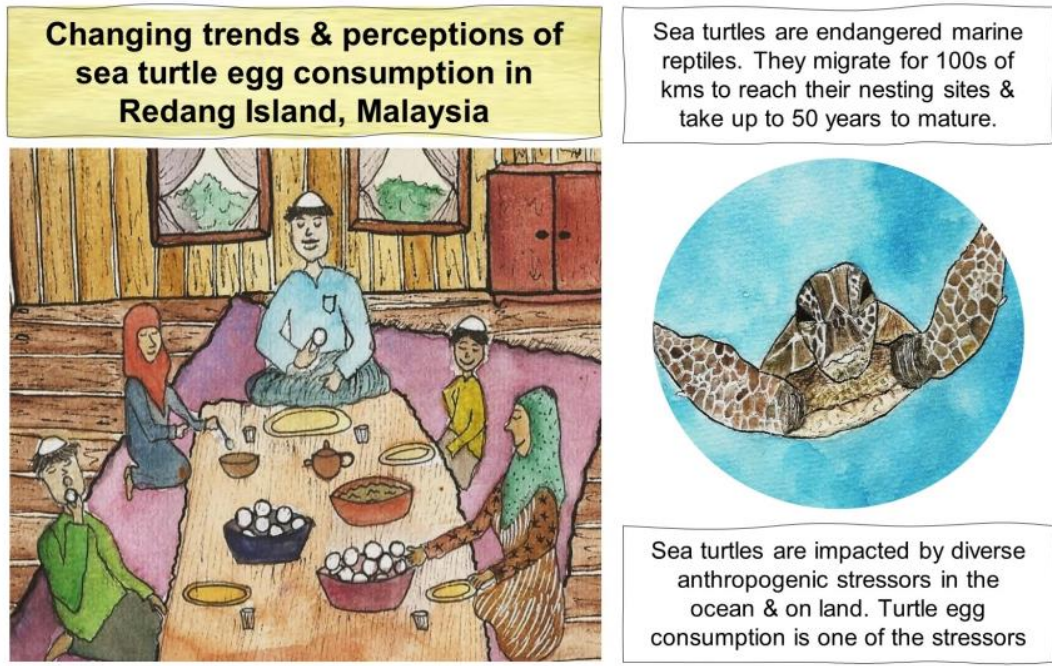

Sea turtles are impacted by diverse anthropogenic stressors in the ocean \& on land. Turtle egg consumption is one of the stressors

For centuries, locals in Redang have consumed turtle eggs as a delicacy, cultural food \& traditional medicine

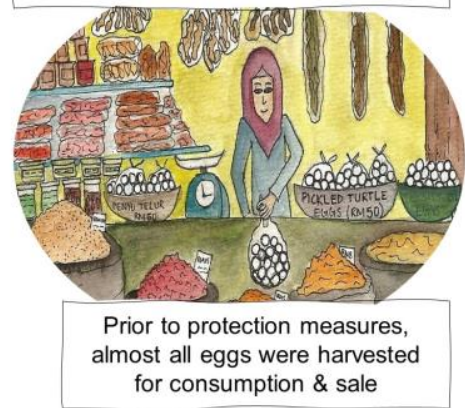

We conducted 73 semi-structured interviews to understand the prevalence, influencing factors \& perceptions on turtle egg consumption

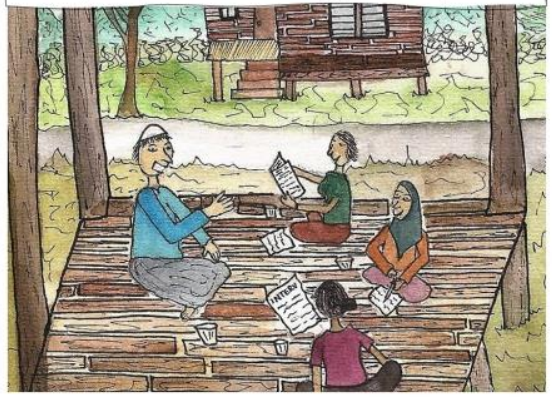

People with higher level of education (younger people) \& those who worked in tourism were less likely to consume eggs

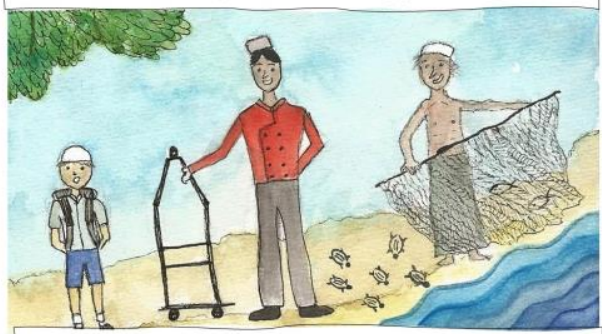

People with lower level of education (older people) were more likely to believe in the medicinal properties of turtle eggs
Due to the rapid decline in turtles, main nesting beaches were protected \& egg collection was prohibited from these sanctuaries

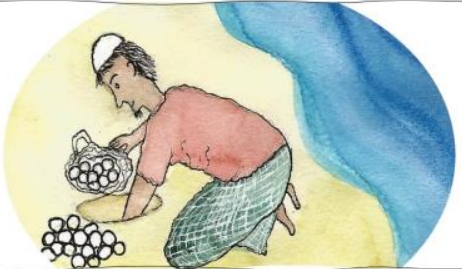

There is no complete ban in the sale \& consumption of green \& hawksbill turtle eggs. This provides some space for locals to continue their practice of eating eggs

\section{Rapid growth in the tourism sector has served as an economic} alternative to turtle egg harvesting

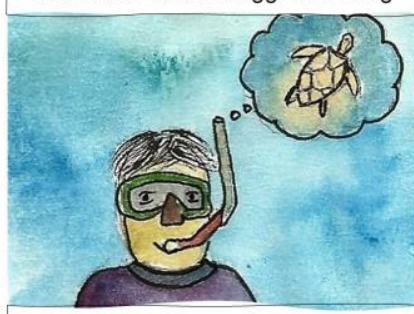

Locals recognize sea turtles as important icons for tourism. Shift from consumptive to nonconsumptive uses of turtles

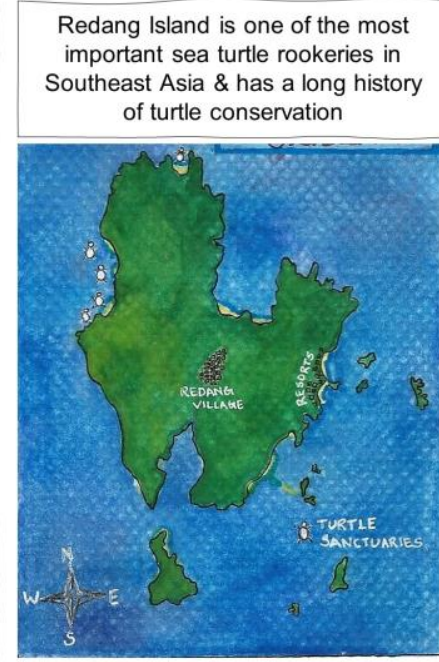

800 local school children attended long-term turtle awareness program \& pledged to stop consuming eggs

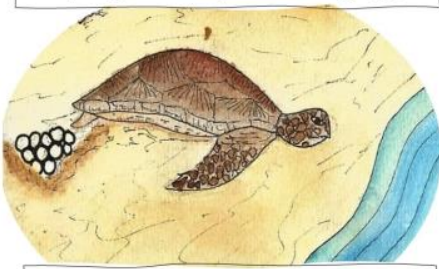

Our study attempts to unravel the complexity of interrelated factors influencing turtle egg consumption in Redang Island

Although $60 \%$ of the respondents consumed turtle eggs, it has become an

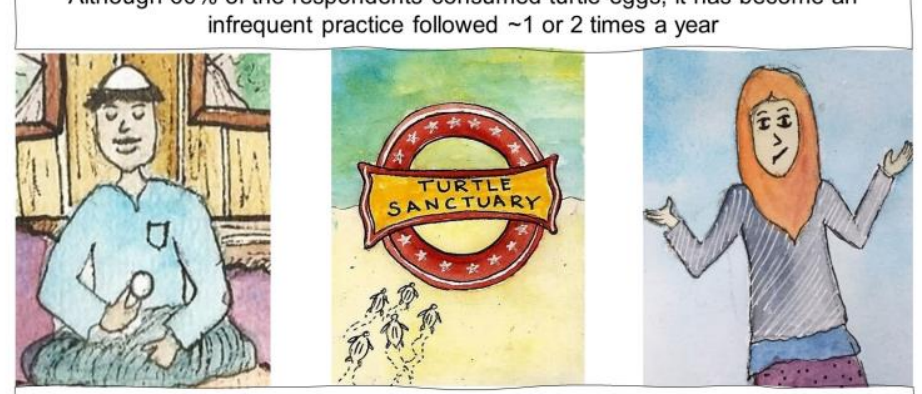

All respondents reported a decrease in egg consumption mainly due to the protection of beaches (decreased availability \& increased price of eggs)

Locals perceived fisheries activities as the most threatening to sea turtle populations. Larger interacting stressors such as fisheries bycatch are poorly addressed by regulations

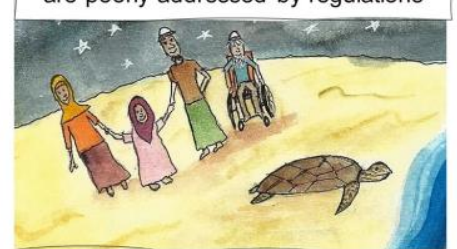

Research \& policy should give attention to the novel human-turtle interactions (fisheries \& tourism) \& not only turtle egg consumption 